\title{
HARTA DALAM PERSPEKTIF ALQURAN: (STUDI TAFSIR AYAT-AYAT EKONOMI)
}

\section{TREASURES IN THE PERSPECTIVE OF ALQURAN: (INTERPRETATION OF ECONOMIC VERSES)}

\author{
Sarmiana Batubara \\ STAI Barumun Raya Sibuhuan \\ Jl. Kihajar Dewantara No. 47-B Sibuhuan Padang Lawas \\ syarmabatubara@yahoo.com
}

Naskah diterima 02 Juli 2018, di-review 01 Agustus 2018, disetujui 09 Nopember 2018

\begin{abstract}
The paper deals with assets in the perspective of Alquran. It consists of the definition of assets, position of assets in Alquran, orders for seeking property, ownership in the views of Alquran, procedures for acquisition and distribution of assets in Alquran. The paper is in the form of literature studies that was conducted by reviewing related books, journals, magazines and articles. It was revealed several things, as the followings: 1) Assets are objects that can be owned, controlled, cultivated, and transferred, both tangible and intangible objects, both registered and unregistered objects, both movable and immovable objects and rights that have economic value; 2) Assets have a very important position in the Qur'an, as proven by the word mall in the Qur'an for 86 times in 79 quranic verses in 38 surah; 3) Orders to work or look for treasures are stated in Alqur'an, such as in surah At-taubah verse 105, Al-Mulk verse 15, AlAnkabut verse 69, and Az-Zumar verse 39; 4) The absolute owner of the mallor everything on this earth is Allah Swt, and human ownership is only relative. It means humans are only ones who have rights for managing and utilizing it as it is; 5) Obtaining mall can be done in various ways, including halal a'mal or ma'isyah. Then, the characteristics distribution of mall are fair and honest, because even in the smallest deeds we do, all will be accounted for in the hereafter.
\end{abstract}

Keywords: treasures, Qur'an, interpretation, economic verses

\begin{abstract}
Abstrak: Jurnal ini berjudul Harta Dalam Perspektif Alquran (Studi Tafsir Ayat-Ayat Ekonomi). Adapun pembahasan dalam tulisan ini terdiri dari: pengertian harta, kedudukan harta dalam Alquran, perintah mencari harta, kepemilikan dalam pandangan Alquran, tatacara perolehan dan pendistribusian harta dalam Alquran. Jurnal ini berbentuk kajian kepustakaan, yaitu dengan menelaah buku-buku, jurnal, majalah dan artikel yang berkaitan dengan tulisan ini. Dalam tulisan ini diungkapkan kepemilikan relatif dalam ekonomi Islam. Kesimpulan pembahasan ini yaitu: 1) Harta adalah benda yang dapat dimiliki, dikuasai, diusahakan, dan dialihkan, baik benda berwujud maupun tidak berwujud, baik benda terdaftar maupun tidak terdaftar, baik benda bergerak maupun tidak bergerak dan hak yang mempunyai nilai ekonomis. 2) Harta memiliki kedudukan yang sangat penting di dalam Alquran, terbukti kata mal dalam Alquran disebut sebanyak 86 kali pada 79 ayat dalam 38 surah. 3) Perintah bekerja atau mencari harta terdapat di dalam Alquran diantaranya pada surah At-taubah ayat 105, Al-Mulk ayat 15, Al-Ankabut ayat 69, bekerjalah sesuai dengan potensi dan kemampuanmu masingmasing Az-Zumar ayat 39. 4) Pemilik mutlak harta atau segala sesuatu yang ada di muka bumi ini adalah Allah Swt, kepemilikan manusia hanya relatif. 5) Cara perolehan harta dapat dilakukan dengan berbagai macam, antara lain melalui usaha ( $a^{\prime} m a l$ ) atau mata pencaharian ( $m a^{\prime} i s y a h$ ) yang halal sesuai dengan aturan Allah Swt. Karakteristik pendistribusian adalah adil dan jujur, karena dalam Islam sekecil apapun perbuatan yang kita lakukan, semua akan dipertanggungjawabkan di akhirat kelak. Pelaksanaan distribusi bertujuan untuk saling memberi manfaat dan menguntungkan satu sama lain.
\end{abstract}

Kata kunci: harta, Alquran, tafsir, ayat-ayat ekonomi 


\section{PENDAHULUAN}

$\mathcal{H}$ parta pada hakikatnya merujuk pada semua pandangan Alquran, itu adalah nikmat Allah SWT, alat-alat provisi (perlengkapan), kesenangan dan kebanggaan. Harta bukanlah sesuatu yang buruk. Alquran menyatakan bahwa ia adalah sesuatu yang baik (khair) dan juga sebagai alat yang membantu kehidupan manusia. Alquran banyak menekankan untuk mempergunakan kekayaan yang dimiliki dalam hal-hal yang baik.

Alquran menyebut kata Al-Mal (harta) tidak kurang dari 86 kali. Penyebutan berulang-ulang terhadap sesuatu di dalam Alquran menunjukkan adanya perhatian khusus dan penting terhadap sesuatu itu. Harta merupakan bagian penting dari kehidupan yang tidak dipisahkan dan selalu diupayakan oleh manusia dalam kehidupannya terutama di dalam Islam.

Islam memandang keinginan manusia untuk memperoleh, memiliki, dan memanfaatkan harta sebagai sesuatu yang lazim, dan urgen. Harta diperoleh, dimiliki, dan dimanfaatkan manusia untuk memenuhi hajat hidupnya, baik bersifat materi maupun non materi. Manusia berusaha sesuai dengan naluri dan kecenderungan untuk mendapatkan harta.

Dalam memperoleh harta, manusia harus tetap pada syari'at, Rasulullah Saw sangat konsern dengan persoalan yang menyangkut dengan kepemilikan harta kekayaan. Beliau sangat memperhatikan dari mana seorang memperoleh harta. Dalam ekonomi kapitalis manusia dibebaskan untuk memperoleh harta benda atau kekayaan sebanyak-banyaknya dengan berbagai cara walaupun dengan cara mengeksploitasi orang lain. Sistem ini akan menimbulkan banyak jurang yang sangat dalam antara orang kaya dengan orang miskin.

Alquran memandang harta sebagai sarana bagi manusia untuk mendekatkan diri kepada Khaliq-Nya, bukan tujuan utama yang dicari dalam kehidupan. Dengan keberadaan harta, manusia diharapkan memiliki sikap derma yang memperkokoh sifat kemanusiannya. Jika sikap derma ini berkembang, maka akan mengantarkan manusia kepada derajat yang mulia, baik di sisi Tuhan maupun terhadap sesam manusia.

Oleh karena itu, harta dalam perspektif Alquran sangat menarik untuk dibahas lebih lanjut dalam tulisan ini.

\section{Rumusan Masalah}

Berdasarkan latar belakang di atas, penulis tertarik membahas dengan rumusan masalah sebagai berikut:

1. Pengertian harta dalam Alquran.

2. Kedudukan harta dalam Alquran.

3. Perintah mencari harta.

4. Kepemilikan dalam pandangan Alquran.

5. Tata cara perolehan dan pendistribusian harta dalam Alquran

\section{Tujuan Penulisan}

Berdasarkan rumusan masalah di atas, tujuan pembahasan ini adalah:

1. Untuk mengetahui pengertian harta dalam Alquran

2. Untuk mengetahui kedudukan harta dalam Alquran 
3. Untuk mengetahui perintah mencari harta dalam Alquran

4. Untuk mengetahui bagaimana kepemilikan dalam pandangan Alquran

5. Untuk mengetahui tatacara perolehan dan pendistribusian harta dalam Alquran

\section{METODE PENELITIAN}

Penelitian ini termasuk jenis penelitian kepustakaan (library research) dengan pendekatan kualitatif. Untuk memperoleh informasi tentang berbagai aspek yang berkaitan dengan persoalan penelitian, yaitu dengan menelaah buku-buku atau sumber-sumber lainnya tentang topik penelitian. Hasil penelaahan disusun berdasarkan tujuan dari penelitian ini.

\section{PEMBAHASAN DAN HASIL}

\section{Pengertian Harta}

Harta dalam Alquran disebut dengan Al-Mal jamaknya Al-Amwal yang secara literal artinya cenderung pada, condong pada, doyong, miring, suka, senang, simpati kepada, menyokong, membantu, melangkah menuju, menyimpang dari, mengelak, berpihak pada dan mengalahkan (Warson, 1984: 1469-1470). Al-Mal khususnya uang merupakan sesuatu yang membuat semua dan setiap orang menjadi suka, bahkan tidak sedikit menggapainya dengan menghalalkan segala cara.

Dalam terminiologi syariat, $\mathrm{Al}-\mathrm{Mal}$ adalah sesuatu yang menurut tabiatnya orang merasa senang dengannya dan memungkinkan pengawetannya dalam kurun waktu tertentu sampai ketika diperlukan pada waktunya nanti (Mardani, 2013: 59).
Menurut Kompilasi Hukum Ekonomi Syariah pasal 1 ayat (9) Amwal (harta) adalah benda yang dapat dimiliki, dikuasai, diusahakan, dan dialihkan, baik benda berwujud maupun tidak berwujud, baik benda terdaftar maupun tidak terdaftar, baik benda bergerak maupun tidak bergerak dan hak yang mempunyai nilai ekonomis (Mardani, 2013: 59).

Dilihat dari jenisnya Amwal dibedakan kedalam dua macam, ada yang berbentuk mata uang yang lazim disebut $A l-N u q u d$ dan ada pula yang berbentuk barang/benda dan jasa yang disebut Al-'Arudh. Al-Nuqud adalah harta yang berbentuk mata uang atau sejenisnya seperti emas, perak, dinar, dirham, uang giral, uang kartal dan lain-lain. Sedangkan Al-Arudh adalah harta yang tidak berbentuk mata uang seperti tumbuh-tumbuhan, perkebunan, atau pertanian, binatang ternak, benda tidak bergerak (tanah, rumah) dan termasuk hak cipta.

\section{Kedudukan Harta dalam Alquran}

Kata mal dalam Alquran disebut sebanyak 86 kali pada 79 ayat dalam 38 surah. Satu jumlah yang cukup banyak menghiasi sepertiga surahsurah Alquran. Dari 86 kata mal itu terdapat 25 kata berbentuk mufrad dengan berbagai lafal, selanjutnya 61 kali dalam bentuk isim jama' (amwal) dan jumlah ini belum termasuk katakata yang semakna dengan mal seperti rizq, mata' dan kanz (perbendaharan) (Tarigan, 2016: 82). Penyebutan berulang-ulang terhadap sesuatu di dalam Alquran menunjukkan adanya perhatian khusus dan penting terhadap sesuatu itu.

Dengan demikian harta memiliki kedudukan yang sangat penting di dalam Alquran, salah satu ayat Alquran yang berkaitan dengan kedudukan harta terdapat pada surah Al-Kahfi ayat 46: 


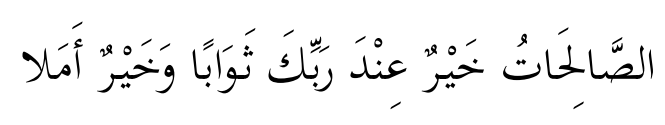

Harta dan anak-anak adalah perhiasan kehidupan dunia tetapi amalan-amalan yang kekal lagi saleh adalah lebih baikpahalanya disisi Tuhanmu serta lebih baik untuk menjadi harapan (Q.S Al-Kahfi [18]: 46)

Kata Al-Mal yang di posisikan sebagai zinah, berfungsi sebagai perhiasan dunia yang kerap melalaikan manusia dari mengingat Allah SWT. Allah Swt menjelaskan bahwa yang menjadi kebanggaan manusia di dunia ini adalah harta benda dan anak-anak, karena manusia sangat memperhatikan keduanya. Banyak harta dan anak dapat memberikan kehidupan dan martabat yang terhormat kepada orang yang memiliknya. Namun karena harta dan anak pula orang menjadi takabbur dan merendahkan orang lain. Allah Swt menegaskan bahwa keduanya hanyalah perhiasan hidup duniawi. Padahal manusia sudah menyadari bahwa keduanya akan segera binasa dan tidak patut dijadikan bahan kesombongan. Dalam urutan ayat ini harta didahulukan dari anak, padahal anak lebih dekat ke hati manusia, karena harta sebagai perhiasan lebih sempurna dari pada anak. Harta dapat menolong orang tua dan anak setiap waktu dan dengan harta itu pula kelangsungan hidup keturunan dapat terjamin. Kebutuhan manusia terhadap harta lebih besar dari pada kebutuhannya kepada anak, tetapi tidak sebaliknya (Tarigan, 2016: 82).

M. Quraish Shihab mengomentari ayat di atas menyatakan, setelah ayat yang lalu melukiskan keadaan dan sifat dunia dengan segala gemerlapnya. Ayat ini menyebut dua dari hiasan dunia yang seringkali dibanggakan manusia dan mengantarnya lengah dan angkuh. Harta dan anak-anak adalah perhiasan kehidupan dunia. Kesemuanya tidak abadi dan bisa memperdaya manusia, tetapi amal yang kekal karena dilakukan karena Allah Swt lagi saleh, yakni sesuai dengan tuntunan agama dan bermanfaat adalah lebih baik untuk kamu semua pahalanya di sisi Tuhanmu serta lebih baik dan lebih dapat diandalkan untuk menjadi harapan (Shihab, 2002: 70).

Selanjutnya penggunaan terminologi Al-Baqiyat Al-Shalihat di ujung ayat tidak dimaksudkan untuk meremehkan anak dan harta. Penggunaan kata Al-Baqiyat yang bermakna kekal hanya ingin membuat perbandingan. Jika ingin meraih kebahagiaan dunia, harta dan anak-anak merupakan sebuah keniscayaan. Hanya saja jika yang ingin di peroleh adalah kebahagiaan yang hakiki, kebahagiaan bersama Allah Swt, pilihlah satu-satunya adalah amal saleh. Andaipun ia menggunakan hartanya sebagai media amal saleh itu bukan disebabkan oleh hartanya, melainkan oleh amalnya yang mensedekahkan atau menginfakkan hartanya. Kendati pun ia memiliki anak yang saleh, itu juga hasil dari amalnya dalam upaya membentuk anak-anak yang saleh (Shihab, 2002: 70).

Dari ayat di atas dapat dipahami bahwa harta merupakan bagian penting dari kehidupan yang tidak dipisahkan dan selalu diupayakan oleh manusia dalam kehidupannya terutama di dalam Islam. Setiap manusia memerlukan adanya harta, ia adalah penopang bagi kehidupan di dunia. Selain itu ia juga menjadi penolong sekaligus beban bagi para pemiliknya di akhirat kelak. Tidak ada seorangpun yang tidak membutuhkan harta. Bahkan seseorang rela pergi pagi pulang petang hanya untuk mendapatkan harta. Tidak 
jarang terjadi pertengkaran dan nyawa melayang hanya karena memperebutkan harta. Setiap orang pada dasarnya menyenagi harta sebagaimana disebutkan Alquran dalam surah Al-Fajr ayat 20:

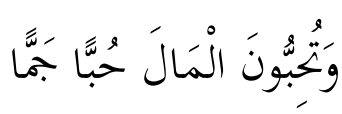

Dan kamu mencintai harta benda dengan kecintaan yang berlebihan (Q.S. Al-Fajr [89]: 20)

Karena cintanya yang berlebihan terhadap harta, maka banyak orang siap melakukan apa saja (penipuan, penggelapan, pencurian, perjudian, penyuapan, perampokan, korupsi, dan lain-lain). Namun demikian, Alquran memberikan rambu-rambu tertentu untuk memperoleh harta.

Salah satu yang perlu di catat, lewat ayat ini, Alquran tidak hanya menyatakan harta itu penting tetapi juga mengakui bahwa harta itu adalah zinah atau perhiasan. Karenanya setiap orang akan berjuang untuk mendapatkan harta tersebut, tentunya dengan cara-cara yang dibenarkan syariat.

Harta dalam pandangan Islam adalah sebagai wasilah atau sarana untuk mencapai kebaikan dan perhiasan hidup serta sendi kesejahteraan dan kemaslahatan hidup manusia. Harta menempati kedudukan yang sangat penting, Islam menempatkan harta sebagai salah satu dari lima kebutuhan pokok dalam kehidupan yang harus dipelihara (Ad-Dharuriyah Al-Khamsah). Ad-dharuriyah Al-khamsah secara berurutan meliputi memelihara agama, jiwa, keturunan, akal dan harta (Rozalinda, 2014: 42).

Meskipun harta menempati urutan kelima dari semua aspek Ad-Dharuriyah Al-Khamsah, ia sesuatu yang urgen dalam memelihara keempat aspek lainnya. Misalnya melaksanakan shalat sebagai bentuk perwujudan memelihara agama membutuhkan pakaian untuk menutup aurat. Makan dan minum dalam rangka memelihara jiwa dapat dipenuhi dengan harta. Memelihara keturunan dengan melaksanakan pernikahan itupun di capai dengan harta. Memelihara akal dengan cara menuntut ilmu adalah dengan harta. Jadi, harta merupakan sesuatu yang sangat vital dalam kehidupan manusia.

\section{Perintah Mencari Harta}

Bekerja merupakan fitrah dan sekaligus merupakan identitas manusia, sehingga bekerja yang didasarkan dan didorong oleh semangat iman, bukan saja menunjukkan kepribadian seorang muslim, tetapi sekaligus meninggikan martabat dirinya sebagai khalifah di bumi ini.

Perintah bekerja atau mencari harta terdapat di dalam Alquran diantaranya pada surah AtTaubah ayat 105:

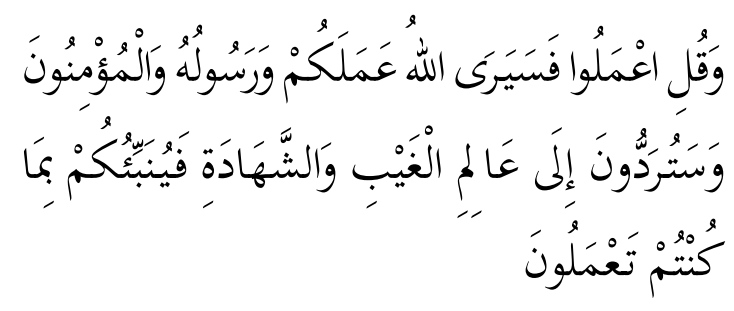

Dan Katakanlah: «Bekerjalah kamu, Maka Allah SWT dan Rasul-Nya serta orang-orang mukmin akan melihat pekerjaanmu itu, dan kamu akan dikembalikan kepada (Allah SWT) yang mengetahui akan yang ghaib dan yang nyata, lalu diberitakan-Nya kepada kamu apa yang telah kamu kerjakan". (Q.S. At-Taubah [9]: 105)

Ayat di atas menginformasikan tentang arti penting penilaian Allah SWT, penilaian Rasul-Nya, dan penilaian orang-orang mukmin terhadap prestasi kerja seseorang. Semua prestasi itu pada 
saatnya nanti di akhirat, akan diinformasikan dan diperlihatkan secara transparan apa adanya, baik yang tersembunyi maupun yang tampak. Singkatnya, setiap yang dikerjakan anak manusia, dipastikan akan diberitakan atau dilaporkan apa adanya.

Adapun tafsir dari ayat di atas adalah "Dan katakanlah Muhammad kepada mereka (orang yang pura-pura beriman padahal sesungguhnya tidak beriman) bekerjalah kalian niscaya Allah SWT dan Rasul-Nya pasti akan melihat prestasi itu dalam bentuk kekayaan, kemampuan, kemuliaan, keleluasan keutamaan rezeki yang tiada tara. Demikian pula, Rasulullah dan orang-orang beriman lainnya, akan menyaksikan prestasi kerja kalian semua sehingga mereka akan memberikan hak-hak kalian di dunia ini, adapun di akhirat kelak itu hendaknya dikembalikan kepada dzat yang mengetahui hal-hal yang ghaib, yang maha mengetahui hal-hal yang bersifat rahasia dan samar sekalipun, serta dzat yang juga Maha mengetahui hal-hal yang tampak (ada), dan Allah Swt pastikan akan memberikan balasan terhadap amal perbuatan kalian semua, baik yang berhubungan dengan prestasi kerja duniawi (bermotifkan ekonomi) maupun yang berhubungan dengan nilai-nilai ukhrawi"(Suma, 2013: 61). Singkatnya jika kerjanya baik, maka akan mendapatkan imbalan yang baik yakni harta yang baik, dan sebaliknya, manakala perbuatan buruk, maka akan mendapat imbalan yang buruk.

Adapun istinbat ayat di atas adalah:

1. Ayat ini pada dasarnya memerintahkan semua dan setiap orang untuk berusaha, termasuk usaha ekonomi yakni mencari harta yang halal sesuai dengan cara yang tidak bertentangan dengan syariat.
2. Semua dan setiap usaha pasti akan diketahui Allah SWT, Rasulullah dan orang-orang beriman secara keseluruhan.

3. Semua dan setiap usaha dipastikan akan menuai balasan/hasil, dan yang berhak memberikan pembalasan atau imbalan itu adalah Allah SWT.

4. Semua dan setiap perbuatan seseorang baik maupun buruk kelak di akhirat akan diperlihatkan apa adanya. (Suma, 2013: 61)

Selain ayat di atas perintah mencari harta juga terdapat dalam surah Al-Mulk ayat 15:

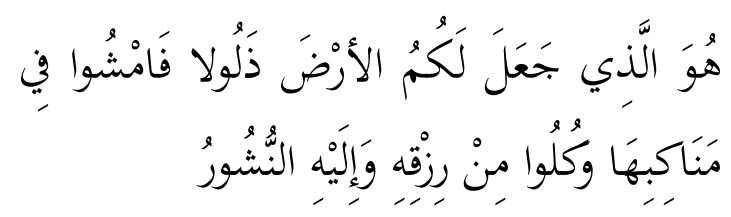

Dialah yang menjadikan bumi itu mudah bagi kamu, Maka berjalanlah di segala penjurunya dan makanlah sebahagian dari rezki-Nya. dan hanya kepada-Nya-lah kamu (kembali setelah) dibangkitkan. (Q.S. Al-Mulk [67]:15)

Menurut Quraish Shihab, paling tidak ada dua pesan moral: 1) ayat ini menjelaskan bumi dimudahkan Allah Swt untuk dihuni manusia, antara lain dengan menciptakannya berbentuk bulat, akan tetapi meskipun demikian ke mana pun kakinya melangkah ia mendapatkan bumi terhampar. 2) di mana-mana ia dapat memperoleh sumber makanan atau rezeki. Kata zalulan terambil dari akar kata zalala yang berarti rendah/hina dalam bentuk zalulan berarti yang penurut, ditundukkan sehingga menjadi mudah.

Jadi Allah Swt telah memerintahkan bumi agar tunduk sehingga mudah dikelola, diatur, dikuasai, dipelihara, dan dilestarikan, maka tidak ada alasan bagi manusia untuk berpangku tangan, 
berdiam diri di rumah menunggu datangnya rezeki. Kemudian kata kunci selanjutnya, yaitu famsyu dan kullu. Lafadz kullu diletakkan setelah famsyu , hal ini menunjukkan karunia Allah Swt akan diperoleh jika telah berupaya mencari rezeki (Shihab, 2002: 356).

Selain kedua ayat di atas, dalam Alquran terdapat beberapa ayat yang menganjurkan untuk berusaha dan bekerja sungguh-sungguh yaitu surah Al-Ankabut ayat 69, bekerjalah sesuai dengan potensi dan kemampuanmu masingmasing Az-Zumar ayat 39, apabila kalian telah menunaikan salat Jum'at, maka bertebaranlah di atas bumi ini mencari karunia Allah Swt AlJumu'ah ayat 10.

\section{Kepemilikan dalam Pandangan Alquran}

Harta pada hakikatnya adalah milik Allah Swt, sedangkan manusia hanya memegang amanah ataupun pinjaman dari-Nya. Allah Swt adalah pemilik harta karena dialah yang menciptakannya, Allah Swt pula yang menciptakan sumber-sumber produksi dan yang memudahkan sarana untuk mendapatkannya. Kemudian Allah Swt lah yang menciptakan manusia dan seluruh alam semesta ini.

Sesungguhnya hanyaAllah Swtyangmenciptakan segala sesuatu yang ada di alam semesta, semua yang ada di alam ini adalah milik Allah Swt. Firman Allah Swt dalam surat Al-A'raf ayat 128.

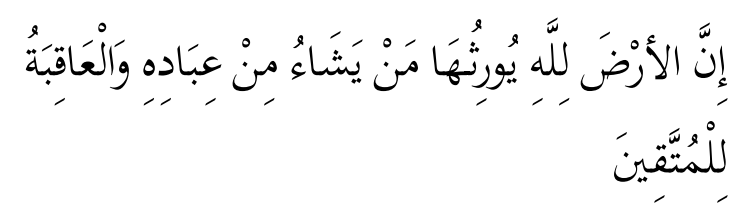

Sesungguhnya bumi (ini) kepunyaan Allah Swt; dipusakakan-Nya kepada siapa yang dihendakiNya dari hamba-hamba-Nya. Dan kesudahan yang baik adalah bagi orang-orangyang bertakwa. (Q.S. Al-A'raf [7]:128)

Ayat ini menceritakan kisah Fir'aun yang merasa sangat berkuasa atas bumi ini, ayat ini merupakan nasihat Musa kepada kaumnya yang telah cemas, mereka mesti memperkuat benteng iman mereka kepada Allah Swt, memperteguh kepercayaan. Meskipun Fir'aun telah mengatakan bahwa ia sangat berkuasa melakukan apa yang dia ingini terhadap Bani Isra'il, namun yang mempunyai bumi ini yang sebenarnya bukanlah Fir'aun, tetapi Allah Swt. Di atas kekuasaan Fir'aun ada kekuasaan Allah Swt dan kesudahan yang baik adalah bagi orang-orang yang bertakwa (Hamka, 1985: 40).

Kesimpulan yang disampaikan oleh ayat ini adalah bahwa Fir'aun berkuasa atas izin Allah Swt juga. Yang memberikan kekuasaan itu mampu untuk mencabutnya. Karena itu, jika manusia berupaya sambil meminta pertolongan Allah Swt dan tabah mengahadapi segala tantangan dan rintangan, niscaya akan dianugerahi kekuasaan.

Allah Swt menciptakan bumi dengan segala isinya, kemudian Allah Swt ciptakan manusia. Setelah Allah Swt menciptakan hamparan bumi dan segala isinya, Allah Swt mengajak kepada umat manusia untuk mengambil bagian mereka. Setiap manusia yang hidup di atas bumi, mempunyai hak yang tidak bisa diganggu dan dihalangi oleh orang lain, hak itu mencukupi segala kebutuhan pokok hidupnya (Al-Misri, 2006: 27).

Pemberdayaan manusia atas segala fasilitas kehidupan, bukan berarti dapat menafikan kepemilikan Allah Swt yang hakiki atau aset-aset tersebut. Dan juga tidak bisa dipahami bahwa 
kepemilikan atas harta benda berpindah dari Allah Swt menjadi milik manusia. Kepemilikan manusia hanyalah kepemilikan untuk menikmati memberdayakan harta kekayaan yang ada, bukan sebagai pemilik yang hakiki. Manusia hanya bisa memiliki kemanfaatan dan fasilitas yang ada. Seperti mempunyai tanah untuk dimanfaatkan sebagai tempat tinggal, sebagai lahan pertanian, ataupun sebagai ladang bisnis. Kepemilikan yang ada hanya sebatas mengambil manfaat dan tidak bisa menghilangkan kepemilikan Allah Swt yang hakiki.

Dengan demikian pemilik mutlak harta atau segala sesuatu yang ada di muka bumi ini adalah Allah Swt, kepemilikan manusia adalah hanya relatif, sebatas untuk menjalankan amanah mengelola dan memanfaatkan sesuai dengan ketentuan-Nya.

\section{Tata Cara Perolehan dan Pendistribusian Harta dalam Alquran}

\section{Tata Cara Perolehan Harta}

Di antara fitrah manusia adalah dia akan selalu terdorong untuk memenuhi kebutuhankebutuhannya. Karena itulah, diantara fitrah manusia adalah dia akan selalu berusaha memperoleh kekayaan untuk memenuhi kebutuhan-kebutuhannya serta selalu berupaya untuk meraih kekayaan tersebut. Karena itu setiap upaya melarang untuk manusia memperoleh kekayaan tersebut tentu bertentangan dengan fitrah. Setiap upaya untuk membatasi manusia memperoleh kekayan dengan takaran tertentu juga bertentangan dengan fitrah. Karena itu pula wajar dan alami jika manusia tidak dihalanghalangi untuk mengumpulkan kekayaan dan

146 || Sarmiana Batubara untuk berusaha memperoleh kekayaan tersebut (An-Nabhani, 2009: 64).

Hanya saja, manusia tidak boleh dibiarkan untuk memperoleh kekayaan, mengusahakannya dan mengelolanya dengan cara sesukanya. Caracara semacam ini bisa menimbulkan gejolak dan kekacauan serta mengakibatkan keburukan dan kerusakan. Cara perolehan harta dapat dilakukan dengan berbagai macam, antara lain melalui usaha ( $a^{\prime} m a l$ ) atau mata pencaharian (ma'isyah) yang halal seuai dengan aturan Allah Swt. Firman Allah Swt dalam surah Al-Jum'ah 9-10:

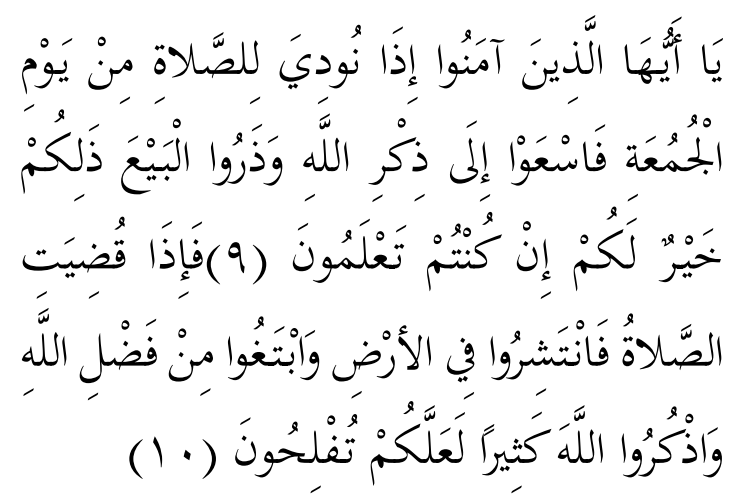

Hai orang-orang beriman, apabila diseru untuk menunaikan shalatJumsat, Maka bersegeralah kamu kepada mengingat Allah Swt dan tinggalkanlah jual beli. yang demikian itu lebih baik bagimu jika kamu mengetahui. 10. Apabila telah ditunaikan shalat, Maka bertebaranlah kamu di muka bumi; dan carilah karunia Allah Swt dan ingatlah Allah Swt banyak-banyak supaya kamu beruntung (Q.S. Al-Jum'ah [62]: 9-10)

Adapun tafsir ayat di atas adalah:

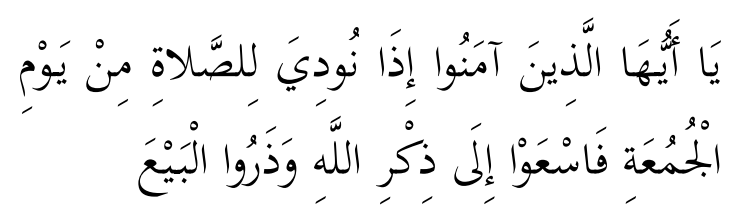

Orang-orang yang beriman dianjurkan supaya segera menunaikan shalat jumat ketika 
azan jumat dikumandangkan. Penggunaaan kata $A l-b a$ 'i dalam ayat ini, dengan maksud meliputi semua kegiatan muamalah (tidak hanya berniaga dalam arti sempit). Meninggalkan aktivitas bisnis dan kegiatan duniawi lainnya untuk sementara waktu demi menunaikan shalat jumat.

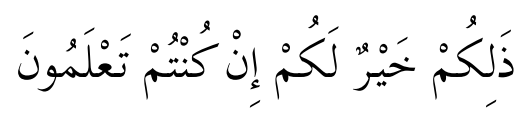

Hal itu jauh lebih baik bagi kamu jika kamu benar-benar orang yang mengetahui, menghayati, dan menjiawi pensyariatan shalat jumat. Kata lebih baik disini, hampir dapat dipastikan tidak sebatas dari sudut pandang peribadatan semamata. Akan tetapi juga dipandang dari sisi lainnya, termasuk dari segi keberkahan perekonomian dan keuangan yang tidak akan pernah merugi.

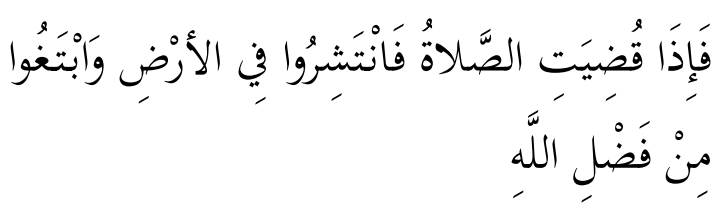

Manakala sudah mengahadiri panggilan azan jumat dan selesai menunaikan shalatnya maka silahkan bertembaran kembali di muka bumi untuk berdagang atau melakukan aktifitas lain yang membawa maslahat bagi kehidupanmu, dan silahkan mencari pemberian Allah Swt dan nikmatnya, mengingat pemberi rejeki yang sesungguhnya adalah Allah Swt.

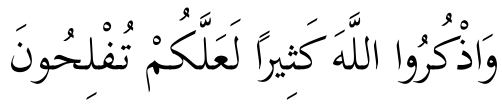

Disaat- saat berdagangatau berbisnis sebaiknya tetap berzikir kepada Allah Swt dengan zikir yang sangat banyak. Intinya, jangan sampai urusan duniawi termasuk bisnis dan semua aktifitas yang bermotifkan ekonomi, itu menyebabkan manusia lupa diri dari hal-hal yang memberikan manfaat buat kehidupan di akhirat kelak (Suma, 2013: 72).

Di dalam Alquran juga terdapat ayat-ayat tentang larangan meperoleh harta dengan cara yang batil, zalim dan haram. Di ataranya: larangan mencari harta dengan cara yang bathil (QS. AnNisa: 29), larangan memperoleh harta dengan cara riba (QS. Al-Baqarah: 275), larangan berjudi (QS. Al-Baqarah: 219), larangan mencuri, merampok (QS. Al-Maidah: 38), larangan curang dalam takaran atau timbangan (Al-Muthaffifin: 1-6), larangan jual beli barang haram (Al-Ma'idah: 91-91), dan larangan risywah/suap menyuap (Al-Baqarah 188).

\section{Pendistribusian Harta dalam Alquran}

Keadilan dan kesejahteraan masyarakat tergantung pada sistem ekonomi yang dianut. Pembahasan mengenai pengertian distribusi pendapatan, tidak terlepas dari pembahasan mengenai konsep moral ekonomi yang dianut juga model instrumen yang diterapkan individu maupun negara dalam menentukan sumber-sumber maupun cara-cara pendistribusian pendapatannya.

Dasar karakteristik pendistribusian adalah adil dan jujur, karena dalam Islam sekecil apapun perbuatan yang kita lakukan, semua akan dipertanggungjawabkan di akhirat kelak. Pelaksanaan distribusi bertujuan untuk saling memberi manfaat dan menguntungkan satu sama lain. Secara umum, Islam mengarahkan mekanisme muamalah antara produsen dan konsumen agar tidak ada pihak yang merasa dirugikan. Apabila terjadi ketidakseimbangan distribusi kekayaan, maka hal ini akan memicu timbulnya konflik individu maupun sosial. 
Oleh karena itu, salah satu upaya untuk mengakhiri kesengsaraan dimuka bumi ini adalah dengan menerapkan keadilan ekonomi. Kebahagiaan akan mudah dicapai dengan penerapan perekonomian yang mendahulukan kepentingan bersama daripada kepentingan individu. Islam menegaskan untuk para penguasa, agar meminimalkan kesenjangan dan ketidakseimbangan distribusi.

Beberapa ayat Alquran tentang pendistribusian harta diantaranya, Allah Swt berfirman dalam surat Al-Hadid ayat 7:

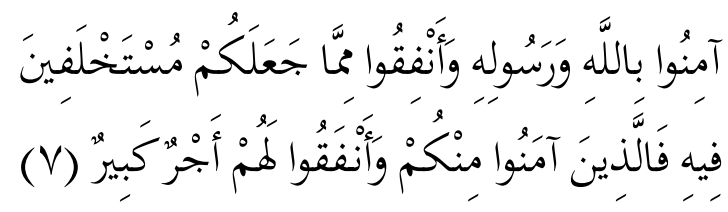

Berimanlah kamu kepada Allah Swt dan rasul-Nya dan nafkahkanlah sebagian dari hartamu yang Allah Swt Telah menjadikan kamu menguasainya. Maka orang-orang yang beriman di antara kamu dan menafkahkan (sebagian) dari hartanya memperoleh pahala yang besar. (Q.S. Al-Hadid [57]:7)

Yang dimaksud dengan menguasai di sini ialah penguasaan yang bukan secara mutlak. Hak milik pada hakikatnya adalah pada Allah Swt. Manusia menafkahkan hartanya itu haruslah menurut hukum-hukum yang Telah disyariatkan Allah Swt. Karena itu tidaklah boleh kikir dan boros.

Di dalam Kitab Tafsir Al-Maraghi dijelaskan penafsiran ayat tersebut di atas, yakni:

1. امنوا بالله و رسوله, akuilah oleh kalian ke-Esaan Allah Swt, dan benarkanlah Rasul-Nya tentang apa yang dia datangkan dari Tuhan kamu.

2. وأنفقوا مما جعلكم مستخلفين فيه, dan belanjakanlah harta yang ada padamu, yang sebenarnya merupakan pinjaman itu, karena harta tersebut pernah pula berada pada tangan umat sebelum kamu, kemudian beralih kepadamu. Dan gunakanlah harta itu dalam ketaatan kepada Allah Swt, kalau tidak maka Allah Swt akan menghisab kamu atas harta tersebut dengan hisab yang berat. Alangkah baiknya perkataan:

$$
\text { وما المال والأهلون إلا ودائع }
$$

Harta dan keluarga, tak lain hanyalah titipan belaka, pada suatu hari titipan-titipan itu pasti dikembalikan.

3. فالذين أمنوا منكم وانفقوا لهم أجر كبير , maka orangorang yang beriman kepada Allah Swt dan membenarkan Rasul-Nya diantara kamu, disamping membelanjakan di jalan Allah Swt harta yang Allah Swt pindahkan kepada mereka dari generasi sebelumnya, mereka akan mendapatkan pahala yang besar disisi Tuhan mereka. Disana mereka akan melihat kemuliaan dan pahala yang tidak pernah dilihat oleh mata, tak pernah didengar oleh telinga, dan tidak pernah terlintas dalam hati manusia seseorang pun (Al-Maraghi, 1989: 287-288).

Dari ayat di atas terdapat 3 hal yang patut kita ketahui, pertama, segala sesuatu yang ada di jagat raya ini termasuk apa yang ada di dalamnya, mutlak dan murni milik Allah Swt. Kedua, manusia hanya diberi amanat dan kekuasaan sebagai wakil untuk mendistribusikan kepada yang berhak. Ketiga, seyogyanya pemilik harta itu tidak boleh bakhil terhadap hartanya, karena 
harta itu merupakan titipan dan amanah dari Maha Pemilik harta tersebut.

Pengertian menafkahkan harta di jalan Allah Swt meliputi belanja untuk kepentingan jihad, pembangunan perguruan, rumah sakit, usaha penyelidikan ilmiah dan lain-lain. Firman Allah Swt dalam surah Al-Baqarah ayat 195:

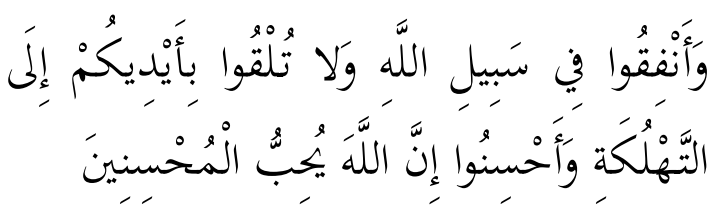

Dan belanjakanlah (harta bendamu) di jalan Allah Swt, dan janganlah kamu menjatuhkan dirimu sendiri ke dalam kebinasaan, dan berbuat baiklah, karena Sesungguhnya Allah Swt menyukai orangorangyang berbuat baik. (Q.S. Al-Baqarah [2] :195)

Dalam Tafsir Jalalain disebutkan riwayat dari Abu Daud dan Thirmidzi yang dinyatakan sah riwayatnya oleh Ibnu Hibban, Hakim dan lainlain, dari Abu Ayyub Al-Anshary, katanya "Ayat ini diturunkan kepada kita dari golongan Anshar, yaitu tatkala Allah Swt menjadikan Islam sebagai agama yang jaya hingga para penyokongnya tidak sedikit jumlahnya, berkatalah sebagian kita pada yang lain secara rahasia bahwa harta benda kita telah habis dan Allah Swt telah mengangkat agama kita menjadi jaya, maka sekiranya kita mempertahankan harta benda itu, lalu menggantinya mana yang telah habis. Maka turunlah ayat menolak pendapat dan rencana ini "Dan belanjakanlah (harta bendamu) di jalan Allah Swt, dan janganlah kamu menjatuhkan dirimu sendiri ke dalam kebinasaan." Sampai akhir ayat. Ibnu Abbas menafsirkan ayat ini dengan menyatakan «Infakkanlah harta-hartamu dijalan Allah Swt yaitu jalan ketaatan padaNya, dan janganlah kalian menahan tangan-tangan kalian untuk memberikan infak di jalan Allah Swt yang berakibat kalian akan celaka".

Kata وأنفقوا في سبيل الله adalah hendaklah kalian berinfak di jalan Allah Swt dengan harta-harta kalian. Karena salah satu fungsi dari harta adalah untuk meninggikan syariat-Nya, yaitu dengan cara menginfakkan di jalan-Nya (Jalalain, 1996: 126).

Dari ayat di atas dapat disimpulkan bahwa di dalam harta yang kita miliki terdapat hak orang lain yang harus disalurkan melalui menginfakkan harta.

\section{PENUTUP}

Berdasarkan dari uraian pembahasan di atas dapat di ambil kesimpulan, yaitu:

1. Harta adalah benda yang dapat dimiliki, dikuasai, diusahakan, dan dialihkan, baik benda berwujud maupun tidak berwujud, baik benda terdaftar maupun tidak terdaftar, baik benda bergerak maupun tidak bergerak dan hak yang mempunyai nilai ekonomis.

2. Harta memiliki kedudukan yang sangat penting di dalam Alquran, terbukti kata mal dalam Alquran disebut sebanyak 86 kali pada 79 ayat dalam 38 surah. Satu jumlah yang cukup banyak menghiasi sepertiga surahsurah Alquran. Diantaranya pada surah AlKahfi ayat 46 dan Al-Fajr ayat 20

3. Perintah bekerja atau mencari harta terdapat di dalam Alquran diantaranya pada surah Attaubah ayat 105, Al-Mulk ayat 15, Al-Ankabut ayat 69 , bekerjalah sesuai dengan potensi dan kemampuanmu masing-masing Az-Zumar ayat 39 , apabila kalian telah menunaikan 
JURNAL IMARA

salat Jum'at, maka bertebaranlah di atas bumi ini mencari karunia Allah Swt Al-Jumu'ah ayat 10 .

4. Pemilik mutlak harta atau segala sesuatu yang ada di muka bumi ini adalah Allah Swt, kepemilikan manusia adalah hanya relatif, sebatas untuk menjalankan amanah mengelola dan memanfaatkan sesuai dengan ketentuan-Nya.

5. Cara perolehan harta dapat dilakukan dengan berbagai macam, antara lain melalui usaha (a'mal) atau mata pencaharian (ma'isyah) yang halal seuai dengan aturan Allah SWT. Sebagaimana dalam surah Al-Jum'ah 9-10 dan beberapa ayat Alquran tentang larangan memperoleh harta dengan cara yang haram, zalim dan bathil. Karakteristik pendistribusian adalah adil dan jujur, karena dalam Islam sekecil apapun perbuatan yang kita lakukan, semua akan dipertanggungjawabkan di akhirat kelak. Pelaksanaan distribusi bertujuan untuk saling memberi manfaat dan menguntungkan satu sama lain. Beberapa ayat Alquran tentang pendistribusian harta kekayaan diataranya QS. Al-Baqarah: 267, Al-Munafiqun: 10, QS. Al-Baqarah: 254, QS. Al-Baqarah 262, QS. Al-Baqarah 264, QS. At-Taubah: 103, QS. Adz-Dzaariyat: 19, QS. Al-Ma'arij: 24-25, QS. An-Nur: 33.

\section{DAFTAR KEPUSTAKAAN}

Akmal Tarigan, Azhari, 2016. Tafsir Ayat-Ayat Ekonomi,Medan : Febi UIN-SU Press.

Amin Suma, Muhammad, 2013. Tafsir Ayat Ekonomi, Jakarta: Amzah.

An-Nabhani, 2009. Taqiyuddin, Sistem Ekonomi Islam, Bogor: Al-Azhar Press .

Hamka, 1985. Tafsir Al-Azhar Juz IX, Jakarta: Jakarta: Pustaka Panjimas.

Imam, Jalalain, 1996. Tafsir Jalalain Jilid I, Bandung: Sinar Baru Algesindo.

Mardani, 2013. Fiqh Ekonomi Syariah,Jakarta: Kencana.

Musthafa Al-Maraghi, Ahmad, 1989. Tafsir AlMaraghi Juz 27, diterjemahkan oleh Bahrun Abu Bakar. Semarang: Toha Putra.

Rozalinda, 2014. Ekonomi Islam Teori dan Aplikasinya Pada Aktivitas Ekonomi, Jakarta: PT. Raja Grapindo Persada

Sami' Al-Misri, Abdul, 2006. Pilar-Pilar Ekonomi Islam, diterjemahkan oleh Dinyauddin Djuwaini, Jakarta: Pustaka Pelajar

Shihab, M. Quraish, 2002. Tafsir Al-Misbah Volume VIII, Jakarta: Lentera Hati

Warson, Ahmad, 1984. Al-Munawwir Kamus ArabIndonesia. Surabaya: Pustaka Progressif. 